\title{
Factor of 'power' in the European vector of Russia's foreign policy strategy and the globalization of energy policy
}

Outline of content: In the modern world of energy dependent economies, the energy component acts as a determining factor in making strategic and political decisions in the geopolitical dimensions. The article's central interest focuses on the economic origins and financial base of the energy component of Russia's aggressive foreign policy in the European space. It contains the qualitative and quantitative indicators of the structure of modern Russian energy market and presents the research of sources of economic basis of Russia's military overcapacity and correlation between the size of defense spending and state budget revenues of the Russian Federation in the energy sector. Based on the findings of this study, possible ways and measures can be modeled to create an effective financial-economic and political-strategic system of the EU states to deter the current course of the Kremlin tight energy policy on the territory of European countries.

Keywords: energy factor, energonomy, militarization of energy policy of the Russian Federation, sectoral sanctions, energy-dependent state

Słowa kluczowe: czynnik energetyczny, energonomia, czynnik siły w polityce energetycznej Federacji Rosyjskiej, sankcje sektorowe, państwa zależne energetycznie

The Russian Federation remains one of the largest exporters of energy in the world market. Occupying a leading position in oil production at the global scale, Moscow provides more than $12 \%$ of the world oil trade. About $23 \%$ of the world natural gas reserves are located in Russian subsoil, contributing a quarter of world trade volumes of this source of energy. Russian nuclear power has a $45 \%$ share of uranium enrichment market, $15 \%$ of reprocessing nuclear fuel market, $5 \%$ of the power generation market, $15 \%$ of the nuclear reactor construction and $8 \%$ of the world production of natural uranium $[1,2,3]$. The oil and gas sector is of vital importance for the stability of the Russian economy, social security, sustainable development of scientific 
and technological projects and a number of other fields of the Russian Federation, which directly or indirectly affect the power of the state. Over the past decade the share of export revenues of oil and gas products in the Russian economy has been growing rapidly. Fig. 1 depicts the dynamics of energy sector revenues to Russia's budget, where oil and gas incomes accounted over $50 \%$ of the federal budget revenues for three consecutive years (2011-2013), that corresponds to about 11\% of GDP.

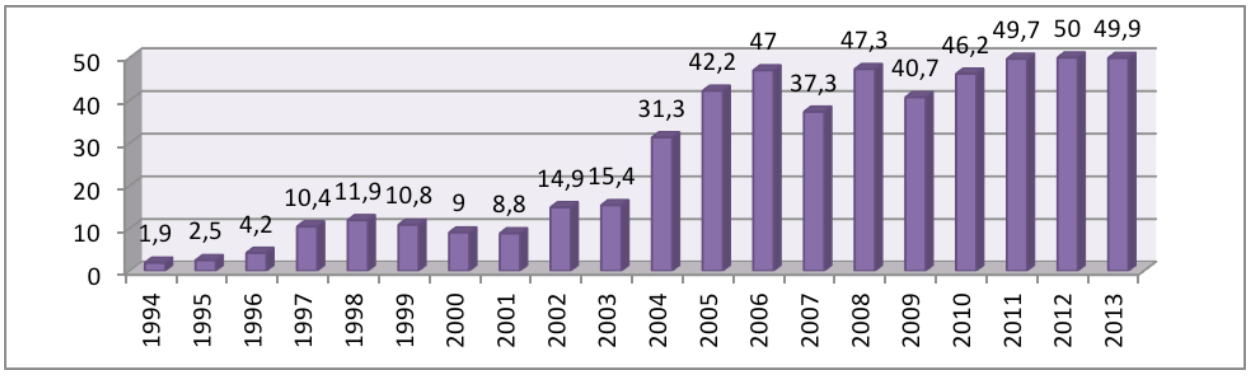

Fig. 1. Share of oil and gas revenues in the federal budget of Russia, 1994-2013 (\%) [4]

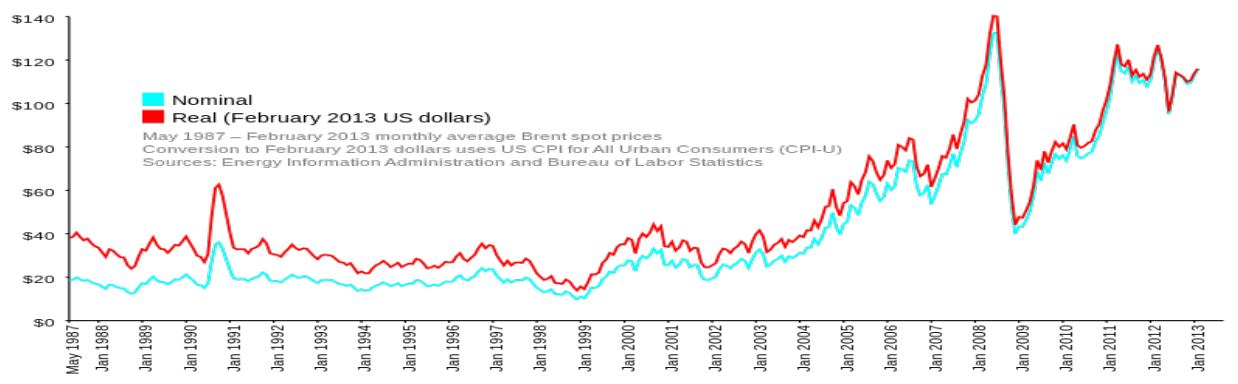

Fig. 2. Dynamics of crude oil Brent prices, 1987-2013 [18]

Under such circumstances, P. Schweitzer, an American researcher of energy geopolitics, is sure that the main reason of political and economic bankruptcy of the Kremlin lies in the decline in energy prices, primarily of oil and gas. In particular, the scholar calculated that the reduction of world oil prices to $\$ 10$ would inevitably increase the Russia's federal budget deficit to $1.4 \%$ of GDP [17, p. 239]. This assumption is based on the direct correlation between the Russian budget and the world oil price. Thus, Fig. 2 shows dynamics of crude oil Brent prices in the energy market, since the given variety of 'black gold' is a basis for shaping the pricing policy for most types of world oil. A price of exported by Russia oil mixture Urals is calculated with a small discount relative to Brent oil. A comparison of the data presented in Fig. 1 and Fig. 2 covering the period from 2003 to 2012, reveals the evident growth of Russia's energy revenues in accordance with the increase of 
world oil prices. A noticeable fall in average prices of the world oil market observed in 2007 and 2009 (Fig. 2) triggered a similar reduction of energy revenues of the federal budget of Russia (Fig. 1). Such a pattern, in our view, serves as sufficient evidence for an opportunity to find a solution offered by the American scientist. Indeed, even a short-term sharp decline in oil prices on the world market in early 2013 caused the actual freezing of budget revenues from energy resources of the Russian Federation at around 49,9\%.

Over the last decade, the energy resources have confidently occupied two thirds of Russian exports (Fig. 3). However, the content of the roll metal products, chemical industry, automobile industry, agricultural products and other components including weapons and agriculture combined with Russia's export balance is three times lower than the corresponding raw-power estimated figure. In the case of major fall in the world prices and demand for oil and gas against the current Russia's negative trade balance in services and exports of finished products, the situation could seriously affect the economy and become a catalyst for a political reboot of the Kremlin. According to the Institute of Energy Research, the Russian Academy of Sciences, as a result of 'anti-Russian political consolidation' in the world arena Russian oil exports could fall by $25-30 \%$, thus reducing the state GDP by more than $\$ 100$ billion [7]. It is not a coincidence that Russian Finance Minister A. Sulianov assessing the risks of economic security of the state in an explanatory note to the federal budget for 2014-2016 focused special attention on oil and gas budget deficit at $10.3 \%$ of GDP in 2013. In his opinion, it makes the economy of Russia extremely vulnerable to external factors. Following this, the statesman set the objectives to reduce the level of non-oil and gas deficit up to $8.4 \%$ by 2016 , thereby to neutralize the possible threats triggered by negative trends in the world energy market [5].

\section{Energy accounts for two-thirds of Russian}

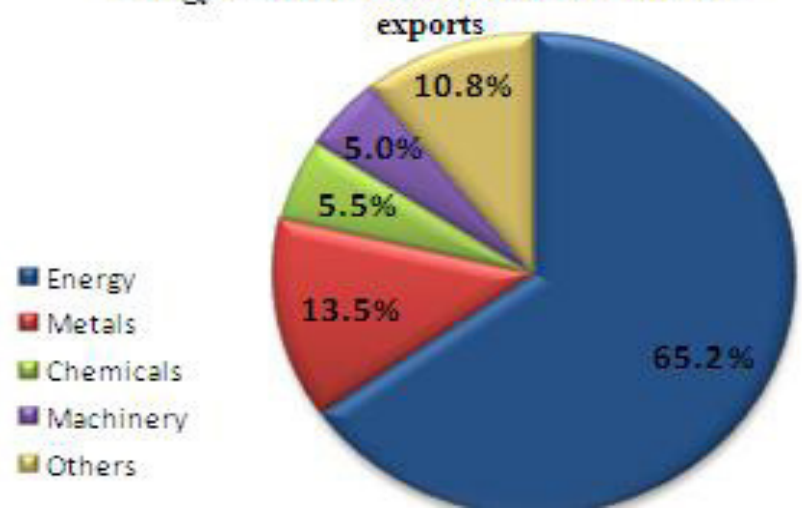

Fig. 3. Structure of export balance of Russia in 2009-2011 [8] 
As noted in the 2012 annual report of the U.S. Energy Information Administration, the majority (79\%) of Russia's crude oil exports went to European countries (including Eastern Europe), particularly Germany, Netherlands, and Poland. Around 18\% of Russia's crude oil exports were destined for Asia and only the remainder (about $3 \%$ ) is exported to the Americas (Fig. 4) [8].

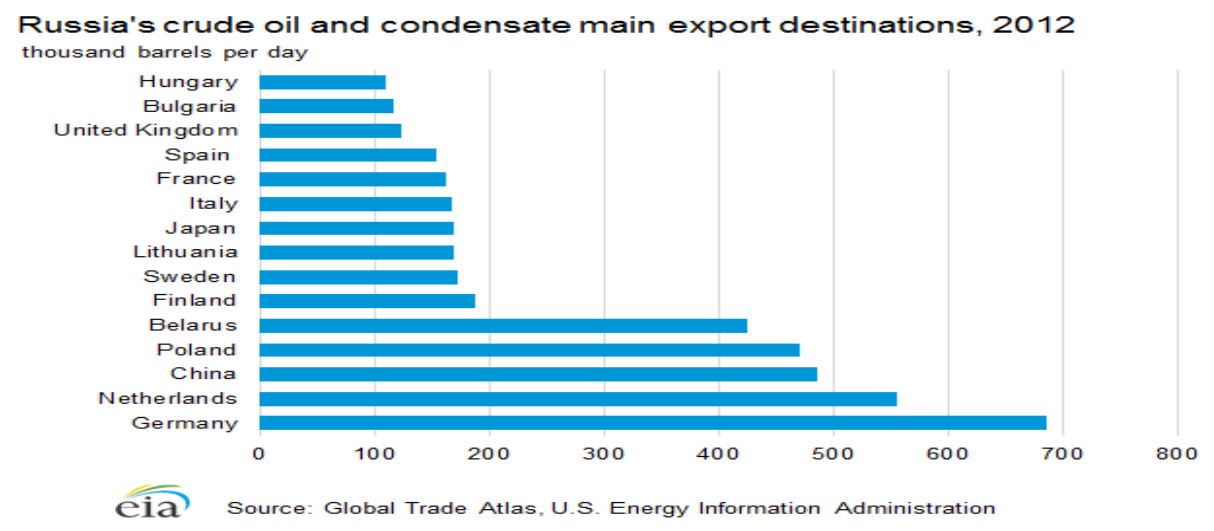

Fig. 4. Russia's crude oil and condensate main export destinations, 2012 (barrels per day) [8]

Russia sends more than $76 \%$ of its natural gas exports to customers in Western Europe, with Germany, Turkey, Italy, France, and the United Kingdom receiving the bulk of these volumes (Energy VIP-clients). Certain volumes of natural gas owned by Gazprom are shipped to Austria, Finland, and Greece.

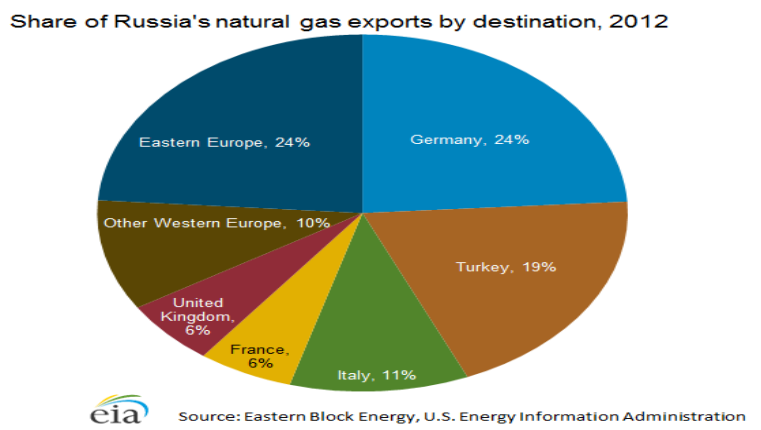

Fig. 5. Russia's natural gas export by destinations, 2012 (\%) [8]

Currently, Russia oil and gas sector remains dominated by state-owned firms. Although, it is worth mentioning that following the collapse of the Soviet Union, the initial privatization of its oil industry took place, but later the energy complex 
has reverted to state control. In the late 1990s, a few privately-owned companies drove growth in Russia's oil sector and a number of international oil corporations attempted to enter the Russian market. Thus, in 2003, British Petroleum (hereinafter: $\mathrm{BP}$ ) invested in Tyumen Oil Company (hereinafter: TNC), forming a joint venture TNK-BP, one of the country's major oil producers. In 2012 and 2013, however, the TNK-BP partnership was dissolved, and BP had to sell its assets to Rosneft company. In the previous century, Rosneft emerged as Russia's top producer following the liquidation of Yukos assets, acquired by Rosneft [8].

ConocoPhillips entered Russia's oil exploration and production in the 1990s, but the attempts to increase its investments were unsuccessful. In particular, in 2004 Lukoil, the second-largest after Rosneft Oil Company in Russia, signed a strategic agreement with ConocoPhillips. As a result, in 2010 Lukoil owned 20\% of Russian assets of the said U.S. oil company. So far it is a single joint oil exploration project of American Exxon Mobil Corporation and Rosneft for developing the Arctic shelf and the Black Sea (Fig. 6).

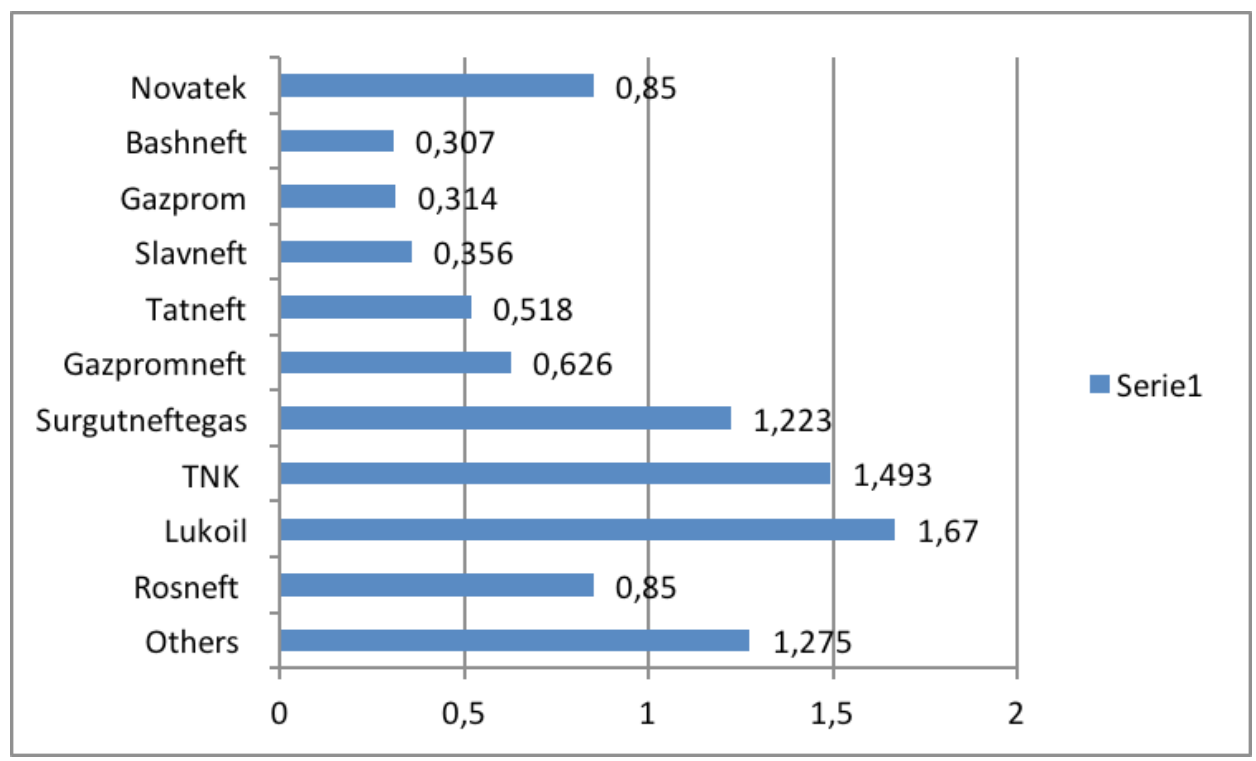

Fig. 6. Oil production by Russian companies, 2012 (thousand barrels/day) [8]

Russian company Gazprom is a dominant player in the national gas market with a share of $74 \%$, while controlling nearly $65 \%$ of proven gas reserves. In addition, Gazprom has legal monopoly on Russian gas exports. The fate of other companies in the Russian gas market is not significant as shown in Fig. 7. Thus, the Russian gas market is virtually monopolized by the state-owned Gazprom company. 


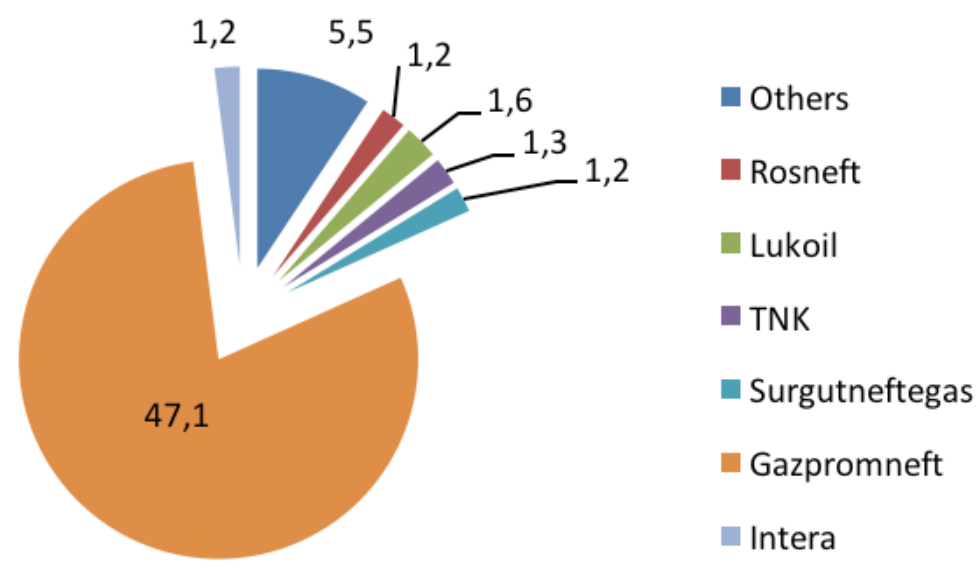

Fig. 7. Natural gas production by Russian companies, 2012 (kBq/day) [8]

The conclusion from the above statistical analysis is obvious. Over the last decade, Russia's federal budget is directly dependent on the profitability of the oil and gas industry. In this sense, it is important to focus on the fact that the Russian energy sector is almost entirely monopolized by the state, while the Russia's ruling elite is, say, the top management of the energy sector. Under such circumstances, the country's leaders gained a wide financial support for significant flow of remittances into the national economy and biased distribution of energy resources, as well as the opportunity to direct significant resources to achieve their strategic interests at both the regional and global levels. In this connection, considerable efforts are directed by the Kremlin to maintain high world prices for hydrocarbons and to preserve the excessive energy dependence of actors of international relations in the field of Russian national interests.

At the same time, the circumstances under which two-thirds of Russia's exports are contributed mostly by energy products have a controversial impact on geopolitical ambitions of Russia. On the one hand, the Russian Federation, positioning itself as an 'energy superpower' in Eurasian continent, skillfully and purposefully uses the energy power factor for forming a 'club' of loyal energy-dependent European countries. This strategy allows Moscow - through its energy-motivated 'lobby' - to affect easily in critical situations all key foreign policy decisions of the EU in a way positive for Russia. On the other hand, an excessive dependence of the national economy on energy revenues is the weakest link in geopolitical 'game' of the Russian ruling elite. In the case of accidental coincidence of circumstances on the world energy market, in particular the generated collapse of world oil and gas prices, a potential for instability emerges inside the Russian state. So, there is the likelihood of an external destructive impact on Russia's social and political bal- 
ance. The use of the power factor makes it possible for Russia to provoke a strong economic collapse and crisis in the territory of the Russian Federation, that is 'to undermine the situation from the inside.

The understanding of the situation currently prevailing at the global energy market in the second part of the twentieth century enabled L. Woodhill, the analyst of Forbes publication, in his article 'It's Time To Drive Russia Bankrupt' to reach a conclusion as to a direct connection between the Soviet military activity and growth of world energy prices. In particular, by analyzing the dynamics of energy prices since the mid-twentieth century, the author argues that 'on an end-of-year basis real crude oil prices averaged $\$ 17.66 / \mathrm{bbl}$ from 1950 to 1972 . By the time that R. Reagan took office they had almost quintupled to $\$ 85.98$. It was this oil price windfall that fueled Soviet expansionism in the 1970s' [13], the scholar sums up. We consider that such position of the American scholar deserves attention of the scientific community, since, exactly in the end of the 1970s when the hydrocarbons price reached historical maximum at that time, the Soviet Union dared to launch a military campaign (the Soviet invasion of Afghanistan in 1978). Besides, comparing the dynamics of prices for hydrocarbons in the 1970s and the increased activity of the USSR (Russia) in local conflicts during the selected period (Egypt: 1969-1974, Syria: 1973, Cambodia: 1970, Bangladesh: 1972-1973, Angola: 1975-1979, Mozambique: 1975-1979, Ethiopia: 1977-1979, Afghanistan: 1978-1989), one can follow a definite dependence, which can be represented by the formula: a continued growth of energy cost stimulated the aggressive Soviet foreign policy. Pursuing the research on the issue at the present stage and comparing the price development for Brent crude oil over the 1987-2013 period (Fig. 2), it is hard not to notice the coincidence in time of the invasion of the Russian Federation on the territory of Georgia (2008) with the next historical maximum in raw material costs. Finally, the continuing growth in world energy prices in late 2013 - early 2014 coincided with another aggression of Russia against the Ukrainian state in the Crimea. Taking into account the Kremlin aggressive behavior in the international arena, the US President B. Obama on 28 March 2014 left for a short-term visit to Saudi Arabia. The expected subject matter of international negotiations was the possibility of increasing of Er-Riyadh oil production and reducing its price to $\$ 80 / \mathrm{bbl}$. The Middle East activities of the U.S. President forced Russia to 'slow down' almost for one month an open military intervention on the territory of Ukraine. However, powerlessness and indecisiveness of the $\mathrm{EU}$ in imposition of economic sanctions due to Russia's flagrant violation of the basic international principle of indivisibility of the territory of a sovereign state along with the success of Russian diplomacy in the energy negotiations in the European theater and the East (China), in early May 2014 encouraged the growth of 'export of Russian mercenaries and weapons' to the eastern regions of Ukraine, navigating from the Russia-Ukraine confrontation to the so-called 'hybrid war' phase.

Analysis of the current situation allows us to make historical parallels and accept the presence of a stable connection between the energy excess profits of Russia and 
its military activity on a global scale. Below, we are going to support and convincingly argue our position with the help of empiric material.

The Stockholm International Peace Research Institute (SIPRI) estimates that world military expenditure in 2013 totaled $\$ 1.75$ trillion. In this list of world's top countries with the highest military expenditure for 2013 the first place is occupied by the United States with the budget of $\$ 640$ billion. China's military expenditure on the army and security is ranked second and makes $\$ 188$ billion, while the Russian Federation is located on the third position, with its last year military expenditure amounting to $\$ 87.8$ billion [15]. An active growth of the expenditure for the army and security sector in Russia as a whole is directly linked to the implementation of the state armament program for 2011-2020. To implement this program, it is planned to spend more than $\$ 705$ billion for purchasing new and modernization of used weaponry. Thus, according to this program, it is planned to upgrade $70 \%$ of all Russian weaponry to modern equipment. Russian military spending during the years between 1992 and 2012 is presented in Fig. 8.

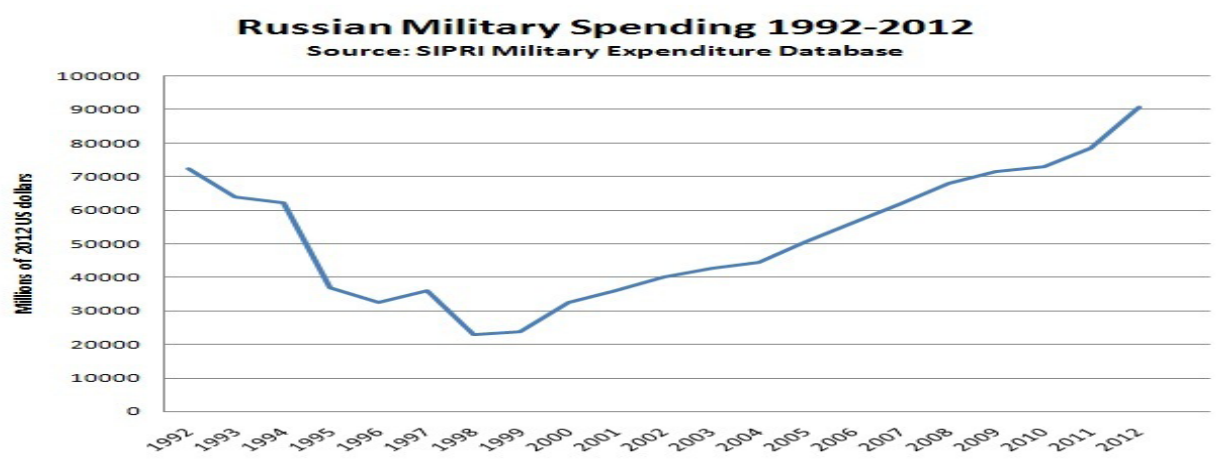

Fig. 8. Russia's military expenditure in 1992-2012 [15]

At present, the expenditures of the 'national defense' chapter of Russia's Federal Budget are increasing both in absolute and in relative terms. As a result, their share in GDP and total expenditures of the federal budget is continuing to grow. It is worth mentioning that in 2013 the growth of military expenditures of the Russian Federation took place. According to analysts T. Tischenko and S. Belev (the Ye. Gaidar Institute for Economic Policy, Russia), one-third of the 2013 budget expenditures under the Law on the Federal Budget for 2013-2015 was allocated on national defense (Fig. 9 presents comparative schedules of ratio percentage of the federal budget to national defense, security and law enforcement compared to spending on education and health for 2010-2015). Russian experts in their study draw the following conclusions: compared to the previous year the major growth of spending falls on the 'national defense' chapter reaching $17.3 \%$ rate or 1.63 trillion rubles and $16.1 \%$ or 198.3 billion rubles fall on the 'applied field of national defense' chapter. This totals 
to approximately one-third of all expenditures of the federal budget [9]. If the 2012 military spending of Russia accounted for $3 \%$ of GDP, this figure according to the federal budget in 2015 would reach the level of $3.7 \%$.

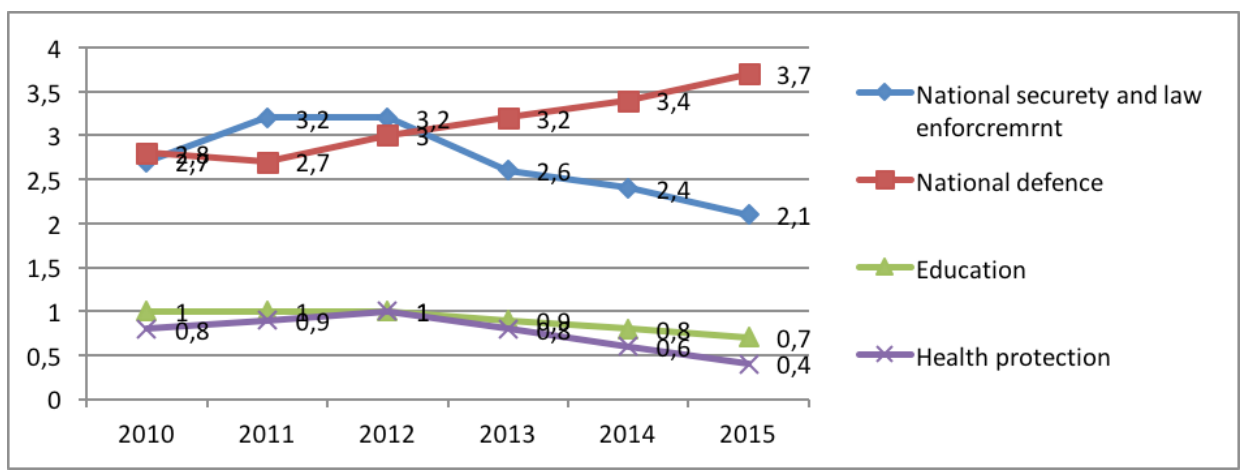

Fig. 9. The expenditure of the federal budget in 2010-2015, \% of GDP [9]

However, the current rapid dynamics of growth of real federal spending on the defense complex can be assessed with the help of the Federal Treasury report on the implementing of the main financial document of the state in January 2014. According to the report the budgetary costs of national defense increased by $18 \%$ compared to the same period in 2013. In the opinion of the head of the military economy laboratory of the Gaidar Institute V. Zatsepin, if the recent trend continues, in 2014 the military burden on Russian economy could reach 5\% of GDP [10]. With this indicator Russia would be able to surpass the United States, spending directly or indirectly - about $4.4 \%$ of GDP on defense each year. However, speaking in absolute terms, the Russian Federation spends on military sector approximately 10 times less than the U.S. (it's about $\$ 70$ billion compared to $\$ 740$ billion a year).

Having analyzed the official documents, the experts of the Gaidar Institute came to a conclusion that the share of secret expenditures of the federal budget has been growing constantly. Over the last ten years this share has risen almost one and a half times: from $11.3 \%$ in 2005 to $16.7 \%$ in 2014 . In other words, within the key sectors of economics considerable sums of the budget are steadily growing in respect of which no purpose is specified. In official documents these needs have not been formulated and the authorities which should account for their use were not specified. In general, it is about 2.3 trillion rubles while two-thirds of this amount fall on defense contracts and the remainder is distributed to financing special services. According to the Russian expert V. Zatsepin, the share of secret expenditures of the federal budget can make up to $25 \%$ in 2016 [10]. In addition, the Russia's Ministry of Finance stated that in 2016 spending of the 'national defense' chapter of the federal budget will grow by $63 \%$ compared to 2013 and amount to 3.418 trillion rubles [11].

The growth of military expenditures is of particular concern to European politicians. In particular, NATO Secretary General A. Rasmussen pointed out that 
over the past five years Russia's military budget increased by $10 \%$, while defense expenditures in Eastern and Central European countries were reduced by $20 \%$ [16]. However, Western experts rightly believe that income received from Russia's trade in energy resources is one of the main sources of finance and basic precondition to hold onto the current authoritarianism in the Kremlin. At the same time, L. Aron, a scholar at the American Enterprise Institute in his article 'The Political Economy of Russian Oil and Gas' contends that petrodollars, the Federal Security Service and television are important tools for survival of Putin's regime [14].

Following the results of our empirical studies (Fig. 1, 8, 9) comparing the government budget revenues from trade of energy resources and federal spending of the Russian Federation in the third millennium, it becomes evident that the state gives priority to profits from the energy sector for re-equipping the defense industry, military modernization and strengthening of the security sector. At the same time the Russian government 'in the lean mode' provides funding for education and science, medicine and culture, social security and so on. Moreover, in recent years there is a clear imbalance in the federal budget between governments spending on defense sector and 'power block' and investment in human capital with considerable preferences in favor of the former. The situation described above is a matter of concern of experts and scientific community about a high probability of the use of a powerful military potential by Russia as a tool for implementation of aggressive foreign policy and an effective method to express its ambitious plans of world leadership and consolidate geostrategic dominance of Russia in the Eurasian theater.

The current behavior of Russia in relation to Ukraine confirms the validity of this concern. After a brutal violation of international law and annexation of Ukraine's Crimea there have been frequent calls among influential representatives of the world's political elite to urge the European Union to impose tough anti-Russian financial economic sanctions. The United States of America, Canada, Australia, Japan and many other countries express their understanding of the need for consolidation efforts of international community against aggressive policy of the Kremlin. In particular, Washington conducted numerous consultations with the leading EU countries and at the EU institutions about joint economic restrictions against the Kremlin. Meanwhile, Hillary Clinton, former Secretary of State of the Obama administration defined a low level of diversification in the modern Russian economy and openly acknowledged the sanctions in the energy sector as the most appropriate powerful lever of pressure on Russia [20].

However, in this sense, there are some concerns and warnings among European countries and the influential EU officials. After all, according to the disappointing forecasts that in case of sanctions on the Russian oil export bans the EU economy would require additionally about 6 million barrels of oil daily. This change in the global market will further trigger a significant jump in energy products prices. A rapid growth in demand for hydrocarbons in Europe will partially refocus the oil field of state-exporters of the Persian Gulf and West Africa from Asian to the 
European market. In turn, there is a significant likelihood that over time a vacant market segment in Asia can be covered by Russia (by the way, some efforts to this end the Kremlin has made concluding a contract for gas supply to China in May 2014). However, the sharp rise in oil prices in Europe would inevitably cause the rise of gas price because according to Gasprom contract it had been calculated using a certain formula that correlates with the oil price. Such a development of the situation in the future will trigger the so-called 'domino effect': the rising cost of logistics services, an increase of light and food industries products, as well as the fuel price hike for services where a fuel-energy component is present. Over time, the combined effects of failure of the European economy from Russian oil in the circumstances of absence of sufficient technical capacity, waste logistic plans and predetermined sources of replacement and alternative supply of raw material would involve the EU into a new round of recession. Traditionally, the objectives of sanctions are to create serious economic difficulties to governments on order to influence their destructive internal or aggressive foreign policy. However, under modern conditions the immediate imposing of oil sanctions towards Russia will have a temporary effect and limited consequences that significantly differ from the expected result. Instead, it will provoke substantial economic complications and tangible financial losses of the European Union states. Whereas, with time the Russian Federation succeeds in diversifying the oil market through the Asian export destination and will gradually resume revenues from the sale of petroleum products and even will be able in the future to increase the profitability of energy business due to the increase of gas price.

This is the opinion of opponents of the EU group of 'pro-Russian anti-sceptics' regarding the imposition of sectoral sanctions on Russia's energy sector. It is clear that the urgent imposition of oil sanctions without the painstaking preparatory phase, proper scientific expert estimation and strong support of international community seems unlikely and would be ineffective. In the near future the EU states will be unable to reach a consensus on the matter and find understanding and support of key consumers of Asian energy market, especially China. Thus, as for today, the imposition of sectoral sanctions by the European community in the energy sector is likely to become an issue of political rhetoric and instrument of psychological pressure rather than a real tool of immediate effective impact on Russia. Initiatives and persistent efforts of Great Britain and Poland, however, regarding restrictions on Russia's energy sector have been embodied in the decision of the European Union on imposing partial sanctions in the selected sector of economy. The reason of London's strict position on this issue was announced by Simon Smith, the British ambassador to Ukraine, who considers that the de-escalation of the conflict in Eastern Ukraine is the main goal of sanctions imposed by the EU. In particular, the head of the Embassy said they did not notice any affirmative action of Russia, clearly requested before, for de-escalation of the situation. He added that on the contrary, Russia was making efforts to destabilize situation in Ukraine [29]. In our view, President Obama gave the most full and inclusive description of the current 
situation on imposing sanctions against Russia in his statement on 25 July 2014. The president noted Russia's and European economies have gotten themselves intertwined especially in the energy sector. Due to this, certain states are most concerned about determined response concerning violation of Ukraine's sovereignty and territorial indivisibility by Russia. Also, the president shared the news that despite some commercial interests Europe supported the U.S. in imposing sanctions on Russia, although not always as quickly as one would like [27].

Putin's team is well aware of the likelihood of a significant financial loss of the economies of countries that dare to apply restrictive measures against Russia in energy sector and does expect a certain pragmatism and rational approach in conduct of Europeans. After imposing of the U.S. economic sanctions on Moscow, the Russian President in his speech focused on financial and economic losses that the American economy would suffer together with the Russian economy [25]. Thus, justifying foreign policy failures of the Russian leadership some members of Russia's industrial community rushed to accuse the U.S. in their efforts to worsen the living standards of ordinary Russians through economic tools of pressure. In such a way, it could trigger social turmoil and discontent with the state's leadership. So, I. Sechin, the chairman of the state energy company Rosneft in a press conference on the Washington sanctions against the budget of his company openly called such a move of the White House as a desire to worsen well-being of the Russian population and undermine confidence of people in the leadership of the state [26]. However, after having become convinced of the documented information in allocating the lion share of budget oil revenues to defense spending, one can easily see a speculation and recognize the lack of truth in the words of the official. Obviously, the reason of imposed economic sanctions on the energy sector is the desire of the world community to calm the excessive militaristic ambitions and aggressive policy of the Kremlin. In support of the view of this situation it is right to quote the words of Geoffrey Pyatt, the U.S. ambassador to Ukraine, who said they did not put sanctions for the sake of sanctions to destroy the Russian economy. In his opinion, it could push the Kremlin to make strategic policy solutions and initiate communication with President Poroshenko [28]. However, according to the words of the head of the Russian energy company, the government is ready to cut the social programs that had been already funded in a restricted mode rather than to end the obsession of creation of the most powerful army in the world even in the absence of a real military threat.

Also, encouraging is the fact that general public will understand the inevitability and objective need for an introduction of tough economic constraints in the case of Moscow's extended territorial aspirations in Eastern Europe. Evidence of expected response of the international community to aggressive actions of the Kremlin is confirmed by the statement of Ukrainian Prime Minister A. Yatsenyuk who at the meeting of the Government commented as follows on the imposition of economic sanctions on Russia by Washington: 'all attempts of the Kremlin to split the European 
Union, to prevent joint actions of the EU and the United States are doomed to failure. It's time to pay for violations of the international law, military aggression, for a constant supply of weapons to Ukraine by Russia, financing of bandits who kill innocent people and try to destroy Ukraine. Russia will pay for the war against Ukraine' [22]. A majority of European countries are aware that there is no alternative and inevitability for tough effective measures of response. During the meeting of the EU foreign affairs ministers (2014) the possibility of imposing a wide range of economic restrictions for calming down the military ardor of the Kremlin was discussed. R. Sikorski, the head of the Polish diplomacy, publicly advocated in favor of imposing sectoral sanctions on the Russian energy sector in response to the war against Ukraine. Unfortunately, however, the EU has not reached the consensus regarding the scope and content of restrictions, although encouraging is a recent statement by German Chancellor Angela Merkel concerning the desirability of imposing significant sanctions against Russia [ 23]. The words of German Foreign Minister F.-W. Steinmeier said in Poland about the inappropriateness of immediate measures in the energy sector are going to significantly narrow the negotiation space with Russia. This move predicts long and difficult negotiations in search of a reasonable compromise and development of an agreed action plan for European countries [21]. A position of the EU Energy Commissioner Günther Oettinger who spoke strongly 'against sanctions in oil and gas sector', not excluding the desirability of making significant economic restrictions in other fields [24], is a direct confirmation of our assumption. However, the current political situation is extraordinary and changes so rapidly that it is unlikely to foresee the development of events. In addition, the 'game' in the energy field is developing so quickly and unpredictably that some data and some information are becoming outdated and losing relevance in the process, requiring reworking of topics and data accessible in near-real time.

So, with the view of creating an effective system of deterrence of the Kremlin aggressive energy policy in the European sector it is necessary to use a full scale of measures as a means of political and economic pressure on the Russian Federation in non-energy field but directly focused on the Russian energy sector. The list of mentioned tools of financial and investment impact includes the following: restricting access to the global financial markets, such as limitation or termination of loans by Western banks or a ban on placement of shares issued by Russian enterprises in world exchanges; refusal of Western companies to invest in Russia's fuel and energy complex, including direct investment in enterprises of different industries and the Russian stock market; the implementation of trade sanctions and embargo on technical equipment, suspension of providing services by foreign companies in Russia's oil exploration, production and extracting and logistics industries and so on. These measures will have tangible negative consequences for Russian economy such as rising cost of loans for Russian companies, increased capital outflows, depreciation of national currency and emigration of skilled professionals in oil and gas sectors abroad. In fact, the financial and investment insulation, the capital outflow and exo- 
dus of intellectual and technical elite also bears a higher risk to the economy and national security of Russia in the long term. Thus, the impact of non-power tools of financial and economic pressure on the energy sector within the collective counter to aggressive manifestations and consolidated opposition to Russia's imperial ambitions may be the most acceptable and economically affordable tool of direct restrictive measures in the energy sector for European community in the future. This can happen under the circumstances of the lack of diversification of European energy market and limited access to alternative energy supplies for the EU states.

At the same time, there is some concern about the EU inability to overcome interstate contradictions and inconsistencies regarding the application of powerful energy sanctions against Russia and some skeptics' disappointing forecasts of deepening discord in the camp of the EU states over implementation of sectoral limitations in the energy sector. Despite of this, the shared understanding of geopolitical expediency prevailed over reluctance of some countries to experience economic losses and the desire to preserve the existing preferences and advantages among other members of the European community in energy relations with Russia. To avoid a probability of such dramatic scenarios for the future development, the EU states should examine the feasibility of establishing a reserve anti-crises European fund in the near future and to count an algorithm of accrual and compensation of possible losses of national economies and minimize financial risks of the EU member states because of the economic sanctions. In particular, the EU states urgently need to develop and implement a mechanism of adequate allocation of economic and financial responsibility for adopting restrictions in the energy sector. In case, the sanctions have been imposed total losses incurred by the EU should also be counted. At this, the potential asymmetrical steps of Russia in response to energy restrictions (in this case, Russia's sanctions on Polish fruits and vegetables) should be taken into account. Thus, the compensation of the losses within the EU joint responsibility for unpopular economic decisions should be proportional to all countries of the European community, for example, depending on the size of GDP and so on. European politicians should draw disappointing lessons from unfortunate present realities and, above all, to revise too cumbersome and highly formalized decision-making procedure of the EU in security field which is having an adverse impact on the situation and makes it difficult to respond quickly and appropriately to challenges of modern world of developed communication and 'online solutions'

However, in the present circumstances of tense situation in the European theater despite the possible financial losses and economic hardship for the population and the EU economy, sectoral sanctions in the energy sector may be the only real effective instrument against aggressive acts of the Russian Federation in the east of European regions. Persistent reluctance of the European community to bear the economic losses and experience restrictions for prompting the Kremlin to return to the international legal framework, might have disappointing political consequences in the future, deepening of crisis in the system of international security and fur- 
ther destabilizing the situation in Europe. Thus, in the case of further escalation of events on the eastern borders of Europe and an increase of aggressive rhetoric of the Russian Federation, the economic sanctions have to become a justified price, which will be paid by the EU states and their people for the sake of peace and security in the short term.

Finally, in the long term, Europe should not reject the progressive, controlled and predictable decline of oil prices in the world market as a factor of effective impact on militarized economy of the Kremlin. Based on our review, the research concluded that the Russian economy is particularly sensitive to international fluctuations in the oil and gas prices. In particular, the price of the formation process in Russian exported energy is directly tied to the crude oil Brent price in the world market, which in turn directly affects the size of the federal budget revenue, which in two-thirds consists of the proceeds from oil and gas sale. So, mathematically calculated economic benefit gained in the case of falling of crude oil Brent prices to $\$ 80 /$ barrel, assuming completion of a situation within one year, will cause an inevitable stagnation and decline of the Russian economy [19]. Of course, a similar trend will be accompanied by the growth of critical negative effects in all areas of social and political life of the country. However, a rapid uncontrolled fall of energy prices will lead to expected disbalance of the global economy. Together with the destabilization of the socio-economic and political situation in Russia, which owns one of the largest nuclear arsenals, it will cause the unpredictable negative consequences on the global scale and will be considered extreme for Europe. Overall, a sharp fall of oil prices can also directly harm the economic interests of the United States. In this situation the U.S. oil and gas shale profitability projects considered as probable sources of energy diversification in European market will lose their economic sense. However, the gradual decline of world oil prices is quite acceptable for the U.S. economy. Analysts predict that prospects of this scenario are an objective reality, which will cause a protracted global financial crisis and decline in industrial production, including a rapid scientific and technological progress which can offer alternative energies [12]. Thereby, the continued but notable decrease in energy prices would permit Europe to stimulate its own economy, at the same time having pacified with the help of relatively painless economic instruments the Kremlin aggressive militaristic ambitions where the lion's share of revenues from trade of energy resources goes to military spending.

Thus, a moderate decline in oil prices would be beneficial to Europe and the U.S. and would play in favor of strengthening geopolitical stability and geo-strategic balance in the world. However, systemic implementation of the outlined scenario of events in the energy market will require coordinated actions of global players together with energy producing states whose economic interests are in conflict with a significant fall in oil prices. Thereby, the United States and united Europe should present to the Persian Gulf states (especially Saudi Arabia) and other members of the 'club of energy states' the acceptable alternative compensation mechanism of 
possible losses, offering the replacement performance of reduced oil price to corresponding proportional increase in oil production, thus leveling negative impact on export-oriented 'energy economy' of the Middle East states. Also, one of the most important tasks of the EU strategic course directed at the compensation of negative effect of the energy factor on the monolithic position and alignment of the euro zone economies in the near future could be the creation of a single European energy market. In particular, a balanced diversification of energy supply in Europe will become an effective way of limiting Russia's excessive impact on the economy and politics of the European Union. The problematic issues highlighted above are more strongly related to the security sector of the interaction between the EU and Russia. But the study of mechanisms for the implementation of depicted scenario of development in the global energy market should be the subject of a separate research and goes beyond the scope of our study.

\section{References}

Петров В.В. Долгосрочные перспективы российской нефти / Петров В.В., Поляков Г.А., Полякова Т.В., Сергеев В.М. - М.: Фазис, 2010. - 213 с.

Накиценович Н. Мировые перспективы природного газа / Накиценович Н. - М.: РХД, 2011. - 189 c.

Годин Ю. Россия: экономика, политика. Геополитическая роль внешней торговли энергоресурсами для России / Ю. Годин // Мировая Экономика и Международные Отношения. - 2011, №2. - С. 103-109.

Илларионов А. Нефтегазовые доходы превысили половину всех доходов федерального бюджета [Електронний ресурс] / А. Илларионов // Особистий блог А. Ілларіонова. Режим доступу: http://aillarionov.livejournal.com/452863.html. - Назва з екрана.

Наганов В. Нефть в обмен на удовольствие [Електронний ресурс] / В. Наганов // Особистий блог В. Наганова. - Режим доступу: http://naganoff.livejournal.com/97670.html. - Назва з екрана.

Oil \& Natural Gas Sector in Russia: Fueling Growth [Електронний ресурс] // Thomas White International. - Режим доступу: http://www.thomaswhite.com/global-perspectives/oil-natural-gas-sector-in-russia-fueling-growth/. - Назва з екрана.

Gold R. U.S. Is Overtaking Russia as Largest Oil-and-Gas Producer [Електронний ресурс] / Gold R., Gilbert D. // The Wall Street Journal - Режим доступу: http://online.wsj.com/news/articles /SB10001424052702303492504579111360245276476? mg=reno64-wsj\&url=http\%3A\%2F\%2 Fonline.wsj.com\%2Farticle\%2FSB10001424052702303492504579111360245276476.html. Назва з екрана.

Overview [Електронний ресурс] // U.S. Energy Information Administration. - Режим доступу: http://www.eia.gov/countries/cab.cfm?fips=RS. - Назва з екрана.

Тищенко Т., Белев С. Федеральный бюджет: равнение на оборону // http://ecpol.ru/macroeconomics/2012-04-05-13-38-34/800-federalnyj-byudzhet-ravnenie-na-oboronu.html. - Назва з екрана.

Зацепин В. Россия обгоняет США по доле оборонных расходов [Електронний ресурс] / В. Зацепин // Інститут економічної політики імені А.Т. Гайдара. - Режим доступу: http:// www.iep.ru/publikatcii/showbib/6691.html. - Назва з екрана. 
Минфин согласился нарастить расходы на национальную оборону на 63\% [Електронний pecypc] // Погляд. Ділова газета. - Режим доступу: http://vz.ru/news/2013/7/2/639680. html. - Назва з екрана.

BP Energy Outlook 2035. [Електронний ресурс] // BP Energy Outlook. - Режим доступу: http://www.bp.com/content/dam/bp/pdf/Energy-economics/Energy-Outlook/Energy_ Outlook_2035_booklet.pdf. - Назва з екрана.

Woodhill L. It's Time To Drive Russia Bankrupt Again [Електронний ресурс] / Woodhill L. // Forbes. - Режим доступу: http://www.forbes.com/sites/louiswoodhill/2014/03/03/ its-time-to-drive-russia-bankrupt-again/. - Назва з екрана.

Aron L. The political economy of Russian oil and gas [Електронний ресурс] / Aron L. // U.S. Energy Information Administration. - Режим доступу: http://www.aei.org/article/the-political-economy-of-russian-oil-and-gas/. - Назва з екрана.

Perlo-Freeman S. Trends in world military expenditure, 2013 [Електронний ресурс] / Perlo-Freeman S., Solmirano C. // Stockholm International Peace Research Institute. Режим доступу: http://books.sipri.org/product_info?c_product_id=476. - Назва з екрана.

Генсек НАТО: Скорочення витрат на оборону в Європі не має виправдання [Електронний peсурс] // Еспрессо.TВ. - Режим доступу: http://espreso.tv/news/2014/05/15/hensek_nato_ skorochennya_vytrat_na_oboronu_v_yevropi_ne_maye_vypravdannya. - Назва з екрана.

Schweizer P. Reigan's War. The Epic Story of His Forty-Year Struggle and Final Triumph Over Communism. / Schweizer P. - N.Y.: Random House. Doubleday, 2003. - 352 p.

Brent spot monthly [Електронний ресурс] // Вікіпедія. - Режим доступу: http://en.wikipedia. org/wiki/File:Brent_Spot_monthly.svg. - Назва з екрана.

Партнерство между США и Россией. Новые времена. Новые начинания / Под ред. Курта Уэлдлона; пер. на рус. American Foreign Policy Council. - Washington, D.C.: Franklin's Printing Company, 2003. - 78 c.

MH17 tragedy: Hillary Clinton calls for tougher sanctions on Russia [Електронний ресурс] // Firstpost. - Режим доступу: http://www.firstpost.com/world/mh17-tragedy-hillary-clinton-calls-tougher-sanctions-russia-1628763.html. - Назва з екрана.

Сікорський і Штайнмайєр розповіли про подальші санкції проти Росії [Електронний peсурс] // УкрІнформ. - Режим доступу: http://www.ukrinform.ua/ukr/news/sikorskiy_i_ shtaynmaye_r_rozpovili_pro_podalshi_sanktsiii_proti_rosiii_1957752. - Назва з екрана.

Яценюк: рішення США та ЄС про запровадження санкцій проти РФ продемонстрували відданість цінностям демократії [Електронний ресурс] // Сайт новин. - Режим доступу: http://www.newsru.ua/ukraine/17jul2014/jazenuk.html. - Назва з екрана.

Меркель підтримала негайні санкції проти Росії [Електронний ресурс] // Електронне видання IPress.ua. - Режим доступу: http://ipress.ua/news/merkel_pidtrymala_negayni_ sanktsii_proty_rosii_76208.html. - Назва з екрана.

Санкції проти енергетичного сектору РФ будуть у кінці списку ЄС, - Еттінгер [Електронний pecypc] // Електронне видання IPress.ua. - Режим доступу: http://ipress.ua/news/sanktsii_proty_energetychnogo_sektoru_rf_budut_u_kintsi_spysku_yes_ettinger_70509.html. - Назва з екрана.

Путин: Американские санкции заводят отношения в тупик [Електронний ресурс] // Press.TV. Режим доступу: http://russian.rt.com/inotv/2014-07-17/Putin-Amerikanskie-sankcii-zavodyatotnosheniya. - Назва з екрана.

Сечин: санкции против «Роснефти» незаконны и необоснованны [Електронний ресурс] // Ітар-Тасс. - Режим доступу: http://itar-tass.com/ekonomika/1322902. - Назва з екрана. Європа підтримала США в питанні санкцій щодо Росії [Електронний ресурс] // Телевізійна служба новин. - Режим доступу: http://tsn.ua/svit/yevropa-pidtrimala-ssha-v-pitanni-sankciy-schodo-rosiyi-obama-360668.html. - Назва з екрана. 
Д.Пайєтт розповів, коли США введуть наступні санкції проти РФ [Електронний ресурс] // Українські національні новини. - Режим доступу: http://www.unn.com.ua/uk/ news/1369261-d-payyett-rozpoviv-koli-ssha-vvedut-nastupni-sanktsiyi-proti-rf. - Назва 3 екрана.

Британия будет поддерживать решительные санкции против РФ - посол [Електронний ресурс] // Канал ICTV. - Режим доступу: http://facty.info/britaniya-budet-podderzhivat-reshitelnye-sankcii-protiv-rf-posol/. - Назва з екрана.

Dr. N. Slobodian received her master's degree in history from Taras Shevchenko National University of Kyiv in 1997. She defended her PhD dissertation on "Iraq in the system of international relations at the end of the 20th century" in 2002 and received a PhD degree in history. In 2013-2014, Dr Slobodian worked as a senior research fellow at the National Research Centre of the International Humanitarian Law and Military Justice Department of the Military Institute within Taras Shevchenko National University of Kyiv. Since 2014 she has been the head of the Energy Department in the International Centre for Policy Studies.

Dr N. Slobodian is the author of the monograph The United States and Russian Federation in the Persian Gulf: Allies - Rivals. She is also the author of over 80 articles on energy issues: 'Energy Factor in American-Russian Relations: Dialogue or Competition,' 'Energy Element of "Force" in Russian-European Relations,', Energy Factor as an Instrument of "Hard" and "Soft" Power in Relations between the US and Russia in the Persian Gulf' and many others. (Наталия Слободская ladynatali03@gmail.com) 